

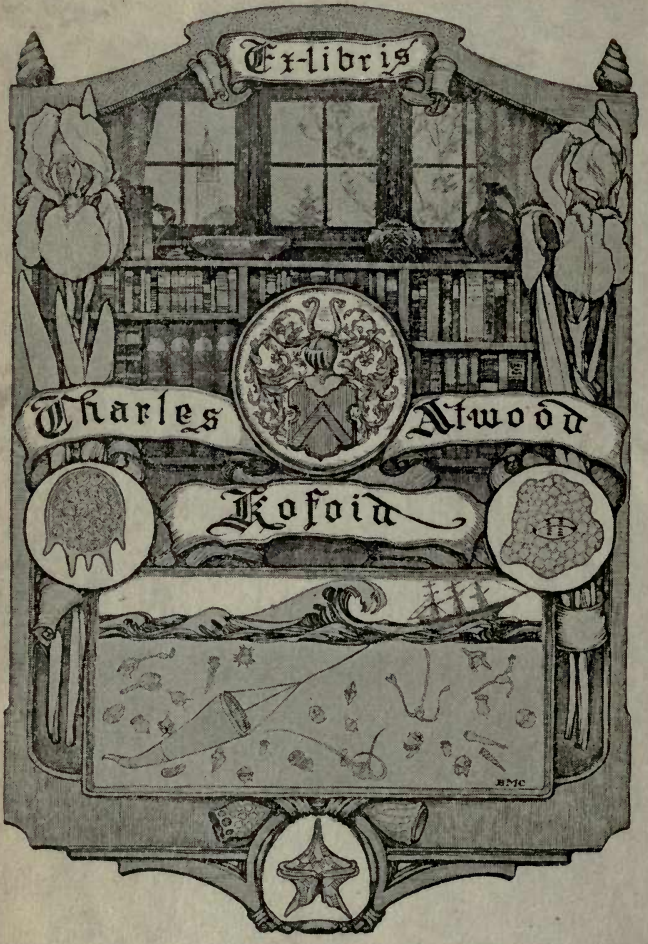




\section{A HANDBOOIK}

BRITISH BUTTERFLIES

J. R. CHARNLEY, F.E.S.

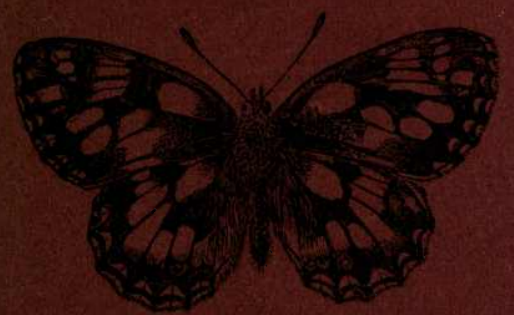

WWTH A PRONTISPIXCE.

\section{LONDON:}

Simpion, Marshali, Hamurton, Kent \& Co., LD. 7902

Price Sixperte. 


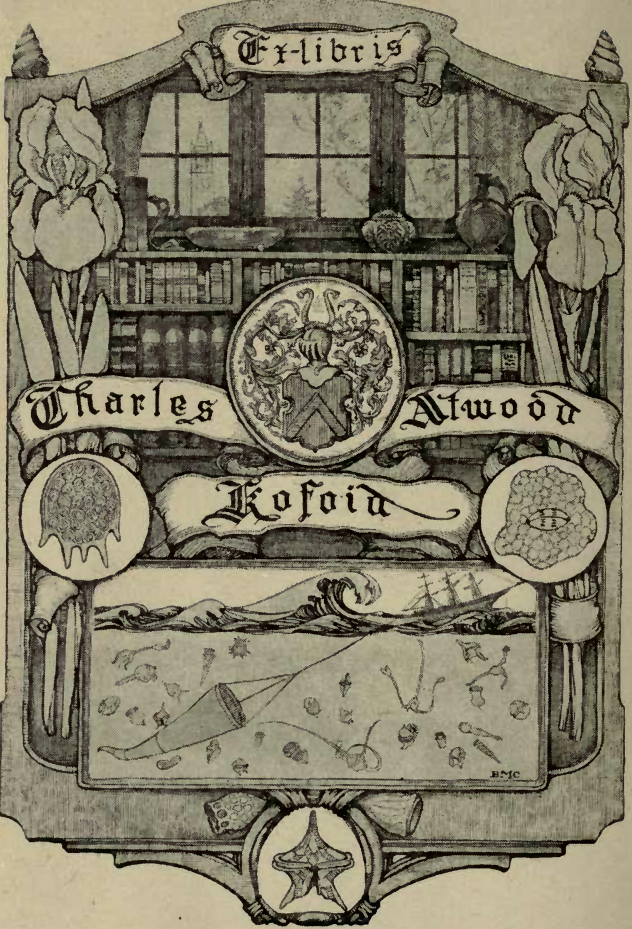

COLLECTING BOXES, \&C Deal. corked and papered, fic.. 9d, 1i. and 186 Qvai Zinc, corked lanswers also for a Relaxine Box). 9d. "Suredeath" Killing Fluid, bd, bottle, frec Illustrited Catalague of Entomalogioal Apparatus Naturat Ova, Larvas and Pupe aiways on hand: Lists Free U'seful Natural History Hanaisook Calendar" "IHustrated);
Calendar". (Jilustrated) illiustrat 
The Practical Scientific Cabinet Makers.

CAI

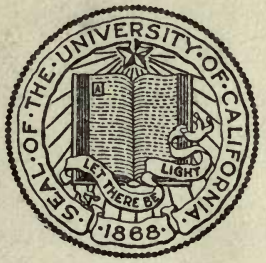

N

\section{OXES.}

i for

teralogists,

Enton

EVE

THE LIBRARY

'ROM.

TERMS

OF

1 Skins.

\section{THE UNIVERSITY} OF CALIFORNIA

d., $3 \frac{1}{2}$ in. $1 / 2$

[S, $3 /-, 4 /-$ 11d., $1 / 5$.

PRESENTED BY

PROF. CHARLES A. KOFOID AND

'S, $1 / 5$ pair.

$\mathrm{r}$ MRS. PRUDENCE W. KOFOID

doz. $7 \mathrm{~d}$

ES, 8d.,

PET,

h Style of ary Setting

All goods not approved may be exchanged, or money returned. All Goods Store Prices. All Best Work.

Estimates given. Great Advantages in dealing direct with Makers.

Send for Full Detailed Price List before ordering elsewhere.

7 A PRINCES ST., CAYENDISII SQ. LONDON, $W$.

FACTORIES : 34 RIDING HOUSE STREET. 


\section{PRICE SIXPENCE.}

\section{"THE ENTOMOLOGISTS' MONTHLY. MAGAZINE,"}

EDITED BY

C. G. Barrett, F.E.S.

G. C. Champion, F.Z.S.

J. W. Douglas, F.E.S.

W. W. FowLER, M.A., F.L.S.

R. McLachlan, F.R.S.

E. SAunders, F.R.S.

Lord Walsingham, M.A., LL.D., F.R.S., \&c.

This Magazine, commenced in 1864, contains Standard Articles on all subjects connected with Entomology, and is more especially devoted to the Insects of the British Isles. A Second Series was commenced in January, 1890.

Subscriptions (Six Shillings per annum post free) may be sent to any one of the Editors, or to the Publishers, as below.

Advertisements concerning Entomology, or Natural Science generally, inserted on very favourable terms.

Communications should be addressed to the Editors, cave of

GURNEY \& JACKSON (Mr. Van Voorst's successors), 1 PATERNOSter ROW, E.c.

\section{Now Ready-THIRD EDITION.}

\section{“The Lepidopterists' Guide."}

Considevably Enlarged, Freely Illustrated, and brought to Twentieth Century Date.

\section{Price One Shilling.}

PUBLISHED BY

GURNEY \& JACKSON, 1 Paternoster Row, E.C.

ALSO SOLD BY

WATKINS \& DONCASTER, 36 Strand, London, W.C. 
A HANDBOOK

OF

BRITISH BUTTERFLIES. 
PRESTON :

LAMBERT BROTHERS, PRINTERS, GLOVER'S COURT.

c 


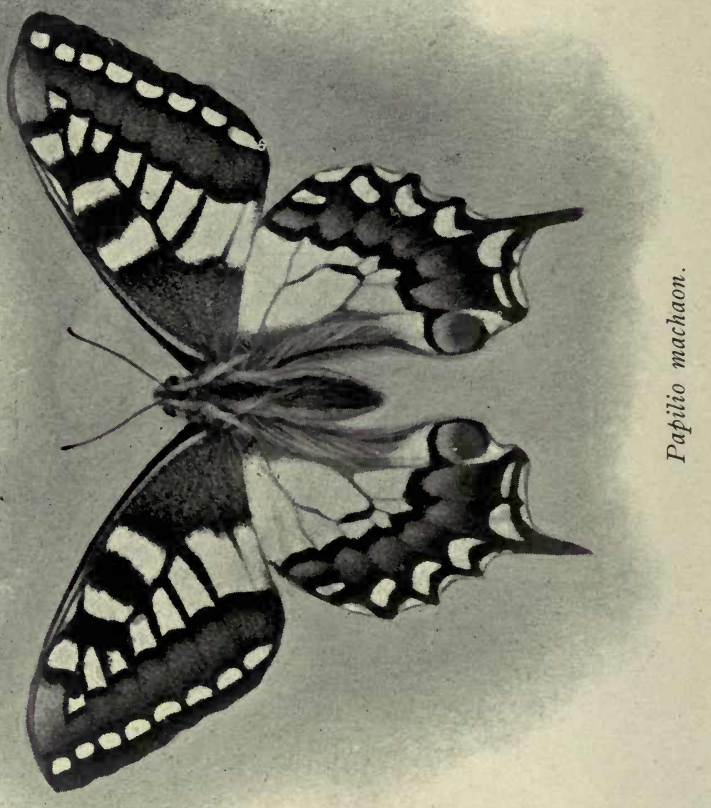




\section{A HANDBOOK}

OF

\section{BRITISH BUTTERFLIES}

BEING

An outline of the distribution of all the

British Butterflies,

TOGETHER WITH

Their Food Plants, Times of Appearance, and Favourite Places of Resort,

J. R. CHARNLEY, F.E.S.

WITH BLANK PAGES FOR NOTES.

LONDON :

Simpkin, Marshall, Hamilton, Kent \& Co., Ld. 1902. 
"Lo, the bright train their radiant wings unfold, With silver fringed, and freckled o'er with gold.

On the gay bosom of some fragrant flower, They idly fluttering live their little hour ;

Their life all pleasure, and their task all play, All spring their age, and sunshine all their day."

Mrs. Barbauld. 


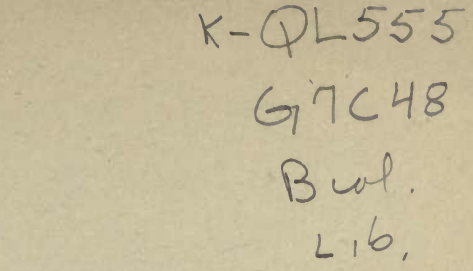

PREFACE.

In the following pages only the true British butterflies (numbering in all 65) have been noticed, the reputed species such as Papilio podalivius, Parnassius apollo, \&c., having been entirely omitted.

The handbook, only pretends to furnish a few brief and elementary notes on each species, and though not intended for the experienced collector, will, it is hoped, prove useful as a pocket companion to the young entomologist.

I desire to express my indebtedness for assistance afforded by a reference to those highly useful periodicals, "The Entomologist" and "The Entomologists' Monthly Magazine," whose pages record a quantity of interesting captures, descriptions of insects, and other useful information from the pens of distinguished entomologists.

I am also under obligations to Mr. W. J. Lucas, B.A., F.E.S., for kind assistance with the proofs.

The order adopted is that of South's "Synonymic List of British Lepidoptera."

Howick,

J. R. C.

May, 1902. 



\section{EXPLANATIONS.}

The information relating to each species is divided into four sections, giving :-

(1) The distribution and abundance * of the species in question ;

(2) The food plants of the larva;

(3) The time of appearance; and

(4) The favourite places of resort.

Section (3), where two months are mentioned thus:"May to July," indicates that the species in question may be seen on the wing from May to July inclusive; and where mentioned thus:- "May and July," with double-brooded species, means the first brood appears in May and the second in July. Of course the time of appearance depends to a certain extent on the forwardness or backwardness of the season.

* Some species vary as regards abundance; of these Pieris brassicæ, Vanessa polychloros, V. io and V. atalanta are examples. 



\section{BRITISH BUTTERFLIES.}

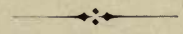

\section{Papilio machaon.-SWALLOW-TAIL.}

1.-This beautiful insect formerly inhabited many counties of England, but the drainage of the fens has so limited the borders of its haunts that it is now almost exclusively confined to the fen districts of Cambridgeshire, Huntingdonshire and Norfolk; and it is to be feared that as the drainage continues it will in time become extinct* in our islands. Unknown in Scotland and Ireland.

2.-Hog's Fennel (Pcuccdamum falustre), Cow-parsnip (Hcracleum sphondylium), and Wild angelica (Angelica sylvestris) in confinement, Rue and Carrot.

3.-May to August.

4.-Fens and marshy places.

* Happily in the Norfolk Broads this is not likely to occur for many years to come.

\section{Aporia cratregi.-Black-Veined White.}

1.-Formerly common in several localities in the South of England, but at all times local; now very rare, and restricted to the county of Kent, but perhaps may still exist in South Wales. Unknown in Scotland and Ireland.* 

2.-Hawthorn (Cratagus oxyacantha) and Sloe (Prunus spinosa); also various fruit trees, Apple, Pear, Plum and Cherry.

3.- June to July.

4.--Isolated heaths and forest lands.

\section{Pieris brassicæ.-Large White.}

1.-One of the commonest of British butterflies, being more or less abundant in all parts of the British Isles.*

2.-Cabbages and various other Crucifera ; Nasturtium, and Mignonette.

3.-Double-brooded; April and July.

4.-Gardens, lanes, and fields.

* Some years this butterfly is seldom seen. (See explanations.)

\section{Pieris rapæ.-Small White.}

1.-Like Brassica, abundant almost everywhere in the United Kingdom.

2.-Cabbages, Horse-radish, Nasturtium, Wild Mustard (Brassica sinapis), Water-cress (Nasturtium officinale), Rape (B. napus), and Wild Mignonette (Reseda lutea).

3.-Double-brooded; April and July.

4.-Gardens, lanes, and fields. 



\section{Pieris napi.-Green-Veined White.}

1.-Though perhaps not quite so common as the last two species, it is met with in most parts of the British Isles, and in many localities is very plentiful.

2.-R̉ape (Brassica napus), Cuckoo-flower (Cardamine pratensis), and two species of Cresses (Nasturtium officinale and Barbarea vulgaris).

3.-Double-brooded; April and July.

4.-Gardens, woods, lanes, and fields.

\section{Pieris daplidice.-Bath White.}

1.-An occasional immigrant only. It occurs most frequently on the South-east coast of England. Unknown in Scotland and Ireland.

2.-Wild Mignonette (Reseda lutea and R. luteola).

3.-Double-brooded; April and August.

4.-Woods, lanes, and meadows.

\section{Euchloë cardamines,-Orange Tip.}

1.-Common, and generally distributed throughout England and the greater part of Scotland and Ireland. 

2.-Cuckoo-flower (Cardamine pratensis), Bitter-cress (C. impatiens), Water-cress (Nasturtium officinale), and Wintercress (Barbarea vulgaris).

3.-May to beginning of June.

4.-Wood clearings, meadows, and lanes.

\section{Leucophasia sinapis.-Wood WHITE.}

1.-Widely distributed but by no means abundant in England; irregularly distributed in Ireland; unknown in Scotland. Apparently becoming more restricted in its range.

2.-Bird's-foot Trefoil (Lotus corniculatus), Tufted Vetch (Vicia cracca), and Bitter Vetch (Lathyrus tuberosus).

3.-Double-brooded; May and August.

4.--Lonely wood glades.

\section{Colias hyale.-Pale Clouded Yellow.}

1.-Like Edusa as regards distribution in England, but much less plentiful. No specimens have been taken in Ireland since 1868; unknown in Scotland,

2.-Bird's-foot Trefoil (Lotus corniculatus), Lucerne (Medicago sativa), and two species of Clover (Trifolium pratense and $T$. repens).

3.-August to October.

4.-Clover and Lucerne fields, and flowery meadows near the sea. 



\section{Colias edusa.-Clouded Yellow.}

1.-It is now, I think, quite settled that this butterfly is an immigrant, and that all the Spring specimens are aliens; the second brood appearing in August is probably the offspring of the Spring immigrants.

Its head quarters in England are the South and Southeast coasts, but it is occasionally common in the Midland counties. It occurs in the South of Ireland, and sparingly in the South of Scotland. Very irregular in its appearance.

Helice is a variety of this species.

2.-Non-such Trefoil (Mcdicago lupulina), Lucerne (M. sativa), and two species of Clover (Trifolium pratcnse and T. repens).

3.-August to October.

4.-Clover and Lucerne fields, railway banks, dry flowery meadlows, open downs, and grassy cliffs.

\section{Gonopteryx rhamni,-Brimstone.}

1.-A common and generally distributed species throughout England, but most abundant in the South. It is occasionally met with in the South of Ireland; unknown in Scotland.

2.-Two species of Buckthorn (Rhamnus frangula and R. catharticus).

3.-July to August, but occurs throughout the year.

4.-Lanes, fields, gardens, and particularly open places in woods. 


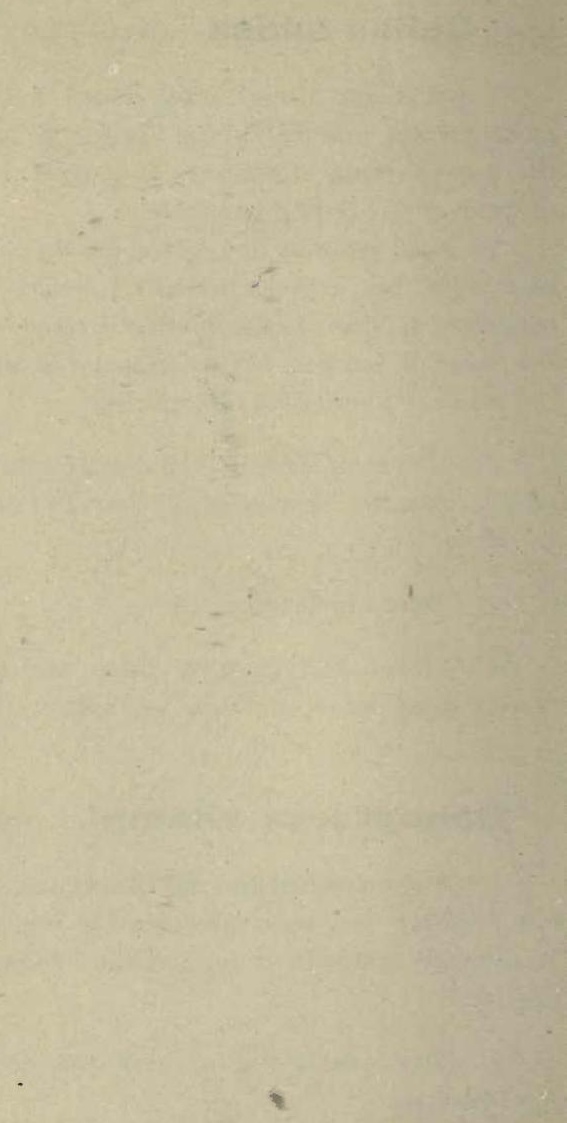




\section{Argynnis selene.-SMALL PEARL-BORDERED Fritillary.}

1.-Widely distributed and generally abundant throughout Great Britain, but like the majority of British butterflies is most plentiful in the Southern counties of England. A single specimen is recorded for Ireland.

2.-Dog Violet (Viola canina).

3.-May to June.

4.-Wood clearings, wood borders, and hill sides.

\section{Argynnis euphrosyne.-PEARL-BORDERED Fritillary.}

1.-In England this is one of the commonest butterflies inhabiting wocds, being met with most profusely in the South. In Scotland it is not so abundant as the last species, and seems to frequent the Northern counties rather than the Southern. Unknown in Ireland.

2.-Dog Violet (Viola canina).

3.-May to June.

4.-Woods and hedge-rows.

\section{Argynnis latona.-Queen of Spain}

Fritillary.

1.-Like Daplidice, an immigrant; it has been observed in about a dozen English counties, particularly those 

bordering the East and South-east coasts. One specimen only has been seen in Ireland; unknown in Scotland.

2.-Heartease (Viola tricolor), Dog Violet (V. canina), and Sweet Violet $(V$. odorata).

3.-September.

4.-Clover fields, and occasionally woods.

\section{Argynnis aglaia,-DARK-GREEN}

Fritillary.

1.-Widely distributed throughout Great Britain and Ireland, but nowhere particularly abundant.

2.-Dog Violet (Viola canina).

3.- July to August.

4.-Heaths, downs, meadows, sand hills, ferny hillsides, and occasionally woods.

\section{Argynnis adippe,-High Brown}

Fritillary.

1.-Not so plentiful as the last species or the next; it has been observed in most English counties, but its head quarters are decidedly in the South. A few specimens were taken in Ireland (co. Galway) some years ago; unknown in Scotland.

2.-Dog Violet (Viola canina), and Heartease (V.tricolor).

3.- July to August.

4.-Wood clearings, borders of woods, heaths, and hillsides. 



\section{Argynnis paphia.-Silver-WASHed}

Fritillary.

1.-The largest and handsomest of the Fritillaries; it occurs frequently throughout England, especially in the Midland and Southern counties; it also occurs plentifully in some parts of Ireland, but is rarely seen in Scotland.

2.-Dog Violet (Viola canina), Sweet Violet (V. odorata), Wild Raspberry (Rubus idaus), and Nettle (Urtica dioica).

3.- July to August.

4.-Outskirts of and open places in woods; especially fond of bramble blossoms.

\section{Melitæa aurinian-Greasy Fritillary.}

1.-Local, but widely distributed; in England and Wales it occurs in nearly all the counties, especially the Southern ones, but does not appear to be particularly plentiful in any. In Ireland it seems to be most plentiful in the South-east, but is met with in various parts of the country; rare in Scotland.

2.-Devel's-bit Scabious (Scabiosa succisa), Honeysuckle (Lonicera periclymenum), Foxglove (Digitalis purpurea), and two species of Plantain (Plantago major and P. lanceolata).

3.-May to June.

4.-Moist woods, meadows, and marshes. 



\section{Melitaea cinxia.-Glanville Fritullary.}

1.-Few British butterflies are more local than this; it was formerly found in Hampshire and other counties in the South of England, as well as a few of the more Northerly ones, but now extinct except in the Isle of Wight.

2.-Narrow-leaved Plantain (Plantago lanceolata).

3.-May to June.

4.-Rough cliffs, landslips, and grassy slopes, near the coast; seems to avoid cultivated districts.

\section{Melitæa athalia.-HeAth Fritillary.}

1.-Another extremely local insect, though usually abundant in its head quarters, the Southern counties of England. It is absent from the Northern counties and also from Scotland, but has been observed in one or two localities in the South-west of Ireland.

2.-Narrow-leaved Plantain (Plantago lanceolata), Broadleaved Plantain (Plantago major), Wood Sage (Teucrium scorodonia), Germander Speedwell (Veronica chamaedrys) and Foxglove (Digitalis furpurea).

3.- June to July.

4.-Wood clearings (particularly where heath occurs), and heaths. 
$x^{2}+x^{2}-2=3$
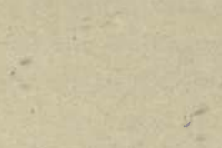

$\frac{1}{4}$

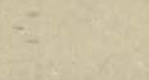

$+$ 


\section{Vanessa C. album,-Cомма.}

1.-Formerly not uncommon in the Midland counties of England, but now local and confined to the West, where its numbers are gradually decreasing; rare in Scotland and Ireland.

2.-Hop (Humulus lupulus), Red Currant (Ribes rubrum), Nettle (Urtica dioica), Elm (Ulmus campestris), and Willow (Salix alba).

3.-July to October.

4.-Orchards, where it feasts on fallen fruit, particularly the Plum, also hedges where brambles and thistles are abundant.

\section{Vanessa polychloros,-LARGE}

TORTOISESHELL.

1.-In England this butterfly is restricted to the Eastern, Midland, and Southern counties, and though generally a rare insect, has not been uncommon of late. ${ }^{*}$ Scarce in Scotland; unknown in Ireland.

2.-Two species of Elm (Ulmus campestris and U. montana) two species of Osiers (Salix viminalis and S. vitellina), Willow (S. alba), Sallow (S. caprea), Aspen (Populus tremula), and various fruit trees, particularly the Cherry (Prunus cerasus).

3.- July to August.

4.-Gardens, woods, and pastures. 


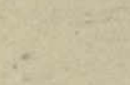

$-$

เ 


\section{Vanessa urticae.-Small Tortoiseshell.}

1.-Another of the commonest of British butterflies, being universally distributed throughout the British Isles.

2.-Nettle (Urtica dioica).

3.- June to October, but occurs in nearly every month of the year.

4.-Flowery gardens, fields, and hedge-rows.

\section{Vanessa io.-PEACOCK.}

1.- Abundant and generally distributed throughout England and the Southern counties of Ireland and Scotland*

2.-Nettle (Urtica dioica).

3.-August to October.

4.-Flowery gardens, fields, and lanes.

* Has been very scarce the last two years.

\section{Vanessa antiopa.-Camberwell. Beauty.}

1.-An occasional immigrant ; prior to 1748 it occurred at Camberwell, Surrey. It has been met with singly in almost every other English county, and not unfrequently in Scotland and Ireland. 

2.-Willow (Salix alba), Birch (Betula alba), and Nettle (Urtica dioica).

3.-August to October.

4.-Woods, gardens, and fields.

\section{Vanessa atalanta.-RED AdMIRAL.}

1.-One of our commonest and handsomest butterflies; abundant almost everywhere throughout the British Isles.

2.-Nettle (Urtica dioica).

3.-August to October.

4.-Flowery gardens and lanes; especially fond of settling on the flowers of the Dahlia, Aster, and Ivy.

\section{Vanessa cardui.-Painted LAdy.}

1.-Though generally a common insect, it is remarkably irregular in its appearance. Some years it literally swarms many localities, while in other years scarcely a single specimen is to be seen; and though it occurs more or less throughout the British Isles, it is impossible to give any definite localities where it constantly appears in any abundance. Probably an immigrant in the Spring, breeding in the Summer.

2.-Various species of Thistle, especially the common Field Thistle (Carduus avvensis); occasionally Nettle.

3.- July to October.

4.-Gardens, fields, and lanes. 



\section{Limenitis sybilla.-White Admiral.}

1.-Formerly more common and widely distributed than now, though still to be met with in a few counties in the South of England; the New Forest is its head quarters. Unknown in Scotland and Ireland.

2.-Honeysuckle (Lonicera periclymenum).

3.- June to August.

4.-Forests, woods, and brambly hedges.

\section{Apatura iris,-PURPLE EMPERor.}

1.-This beautiful butterfly is confined to the oak forests of the Eastern, Midland, and Southern counties of England, where it is not uncommon. Unknown in Scotland and Ireland.

2.-Sallow (Salix caprea) and Poplar (Populus alba).

3.-July to August.

4.-Oak forests and woods, filthy pools and ditches; especially fond of feasting on carrion.

\section{Melanargia galathea.-MARBLED White.}

1.-Not uncommon, but local; it is fairly well distributed over the Midland and Southern counties of England. Unknown in many of the Northern counties and in Scotland and Ireland. 

2.-Timothy Grass (Phleum pratense) and other Grasses.

3.-July to August.

4.-Chalk cliffs, waste grounds, meadows, and rough pastures. Generally confines itself to one particular spot.

\section{Erebia epiphron.-Mountain Ringlet.}

1.-In England this butterfly is almost entirely confined to the Lake District, where it is usually abundant. It is occasionally met with in the Midlands of Scotland, and formerly occurred in the West of Ireland.

Very probably this species and the next, which at present appear local, will in time be found far more widely distributed than is generally supposed, as many of the mountainous districts of the British Isles which they are likely to inhabit are yet to be explored by entomologists.

2.-Annual Meadow grass (Poa annua), and other grasses.

3.-June to July ; males usually appear before females.

4.-Tarns, springs, marshy spots, and rough grassy fields in mountainous districts.

\section{Erebia æethiops.-NORTHERn BRown.}

1.-A tolerably common species in the Southern counties of Scotland, its head quarters, and occurs in some abundance in the Northern counties of England. Unknown in Ireland. 

2.-Various Grasses.

3.- July to August.

4.-Rough fields in mountainous districts.

\section{Pyrarge ægeria.-Speckled Wood.}

1.-Plentiful throughout England, Wales and Ireland, but somewhat uncommon in Scotland, where it is confined to the South.

2.-Various Grasses, especially the Couch-grass (Triticum repens).

3.-Triple-brooded; April, June, and August.

4.-Wood glades and grassy lanes.

\section{Pyrarge megara.-WALL Brown.}

\section{1.-Like Ageria.}

2.-Cock's-foot Grass (Dactylis glomerata), and other grasses.

3.-Double-brooded (sometimes triple); May and August.

4.- Stony banks, roadsides, meadows, and lanes; delights to settle on walls. 



\section{Satyrus semele.-GrayLing.}

1.-Not so abundant as the two last species, but occurs more or less throughout the British Isles. Not uncommon in the South of England, where it often appears in considerable numbers.

2.-Couch-grass (Triticums repens), and other grasses.

3.-June to August.

4.-Rocky and stony places, heaths, and rough elevated pastures.

\section{Epinephele janira.-MEADow BRown.}

1.-This is perhaps the most abundant butterfly inhabiting the British Isles.

2.-Smooth-stalked Meadow Grass (Poa pratensis), and other grasses.

3.- June to August.*

4.-Grassy lanes and meadows.

* A second brood in South Devon last August (1901).

\section{Epinephele tithonus.-Large Heath.}

1.- To be found in greater or less profusion throughout England, and sparingly in the Southern counties of Scotland and Ireland. 

2.-Annual Meadow Grass (Poa anmua), and other grasses.

3.- July to September. ${ }^{*}$
4.-Meadows, heaths, downs, and lanes.

*A second brocd in South Devon last August (1901).

\section{Epinephele hyperanthes.-RINGLET.}

1.-Widely distributed and generally abundant in England, especially in the Midland and Southern counties. It is also met with, though much less frequently, in the Southern counties of Scotland and Ireland.

2.-Annual Meadow Grass (Poa annua) and other grasses.

3.- June to July.

4.-Wood glades, outskirts of woods, and shady corners of flowery lanes.

\section{Cononympha typhon.-MARSH RINGLET.}

1.-Fairly common and generally distributed throughout Scotland and the Ncrthern counties of England, and not unfrequent in the South and West of Ireland.

Rothliebii is a variety of this species, inhabiting the Northern counties of England. 

2.-Värious grasses.

3.- June to July.

4.-Marshy heaths and moorlands.

\section{Cononympha pamphilus.-Small}

HeATH.

1.-A common and generally distributed insect throughout the British Isles.

2.-Crested Dog's-tail Grass (Cynosurus cristatus), Annual Meadow Grass (Poa annua), and other grasses.

3.-Double-brooded; May and August.

4.-Heaths, downs, meadows, and wood clearings.

\section{Thecla betulæ.-Brown HAIRSTREAK.}

1.- Rare but very widely distributed ; it does not appear to be restricted to any particular part of England, but in Ireland it is chiefly confined to the South-west. There is at present no record of its occurrence in Scotland.

2.-Birch (Betula alba) and Sloe (Prunus spinosa).

3.- July to October.

4.-Woods and brambly hedges. 



\section{Thecla W. album.-White Letter \\ HAIRSTREAK.}

1.-Now a rare insect in this country, though formerly not uncommon. It is unknown in Scotland and Ireland, but widely distributed in Eastern and Southern counties of England.

2.-Elm (Ulmus campestris) and Wych Elm (U.montana).

3.-July.

4.-Woods, wolds, and brambly hedges.

\section{Thecla pruni.-Dark Hairstreak.}

1.-Generally a very rare insect, being restricted only to a few English counties, notably Huntingdonshire and Northamptonshire. Unknown in Scotland and Ireland.

2.-Sloe (Prunus spinosa).

3.- June to July.

4.-Woods and wolds.

\section{Thecla quercus,-Purple Hairstreak.}

1.-A widely-distributed species throughout the British Isles. It is the commonest of the Hairstreaks, being met with abundantly in the oak forests of the South of England, and occurs more or less in all the counties. In Scotland it 



\section{3}

chiefly inhabits the Midland and in Ireland the Southern and Eastern counties.
2.-Oak (Quercus robur).
3.- July to August.
4.-Oak woods.

\section{Thecla rubi,-Green Hairstreak.}

1.--Like Qucrcus as regards distribution, but more abundant in Scotland than that species, and not quite so common in England.

2.-Bramble (Rubus fruticosus), Broom (Cytisus scoparius), and Birch (Betula alba).

3.-May to June.

4.-Woods, heaths, and waste places about bramble bushes.

\section{Polyommatus dispar,-LARGE COPPER.}

1.-Formerly abundant in the fens of Cambridgeshire and Huntingdonshire, until about the year 1847, when it rapidly disappeared, and is now absolutely extinct. It was never observed in Scotland or Ireland.

2.-Water Dock (Rumex hydrolapathum).

3.- July to August.

4.-Fens and marshy places. 



\section{Polyommatus phlœas,-Small Copper.}

1.-Common in all parts of the British Isles, except the Northern counties of Scotland.

2.-Broad-leaved Dock (Rumex obtusifolius), Sorrel (R. acetosa), Sheep Sorrel (R. acetosella), and Ragwort (Senecio jacobaea).

3.-Triple-brooded; April, June, and August.

4.-Heaths, meadows and woods.

\section{Lycana agon:-Silver-STUdded Blue.}

1.-Generally speaking, a Southern insect, but occurs throughout England, and more rarely in Scotland and Ireland.

2.-Bird's-foot (Ornithopus perpusillus) and Furze (Ulex europous).

3.- July to August.

4.-Heaths, commons, downs, and dry sandy spots.

\section{Lycrena astrarchen-BROWN ARGUS.}

1.-A widely distributed insect in England; most abundant in the South; has been observed in the West of Ireland; unknown in Scotland.

There are two varieties of Astrarche hitherto regarded by many entomologists as distinct species-they are Salmacis 

and Artaxerxes; the former inhabits the North of England, and the latter the Midland and Southern counties of Scotland.

2.-Hemlock Storksbill (Erodium cicutarium), and Rock Rose (Helianthemum vulgare).

3.-Double-brooded; May and August.

4.-Chalky districts.

\section{Lycana icarus.-COMmON BLUE.}

1.-Abundant nearly everywhere throughout the British Isles.

2.-Bird's-foot Trefoil (Lotus corniculatus), Rest-harrow (Ononis spinosa), and two species of Clover (Trifolium pratense and $T$. repens).

3.-Double-brooded; May and July.

4.-Meadows, heaths, downs, and waste places.

\section{Lycrena bellargus,-C}

1.-Confined to the chalk districts of the South of England. Unknown in Scotland and Ireland.

2.-Clover (Trifolium repens) and Horse-shoe Vetch (Hifpocrepis comosa).

3.-Double-brooded; May and August.

4.-Chalky downs. 



\section{Lycæna corydon.-ChalK-hill Blue.}

1-Generally abundant in most chalky districts in the South of England, but its range extends to the Northern counties. It is not recorded for Scotland or Ireland.

2.-Bird's-foot Trefoil (Lotus corniculatus), Kidney Vetch (Anthyllis vulneraria), and two species of Clover (Trifolium pratense and T.repens).

3.- June to July, often much later.

4.-Chalk and Limestone districts.

\section{Lycæena argiolus.-Holly Blue.}

1.-Abundant in the South of England, but speedily decreasing in numbers towards the North. In Ireland it is widely distributed and not uncommon, but there is no record of a Scotch specimen.

2.-Holly (Ilex aquifolium), Ivy (Hedera helix) and Dogwood (Cornus sanguinea).

3.-Double-brooded in the South of England; May and August.

4.-Woods and hedges, especially where Holly and Ivy are abundant.

\section{Lycæna semiargus.-Mazarine Blue.}

1.-Formerly not uncommon in the Midland and Southern counties of England, but now, I fear, quite extinct as a British species. It was never observed in Scotland or Ireland. 

2.-Said to be the flower heads of the Thrift (Armeria vulgaris).

3.-June to July.

4.-Rough fields in chalky districts.

\section{Lycæna minima.-- Little Blue.}

1.-Widely dispersed throughcut England; it is absent from many of the counties, but is not uncommon where it occurs. In Scotland it is local, resorting chiefly to the Midland and South-western counties. It occurs in various parts of Ireland.

2.-Kidney Vetch (Anthyllis vulneraria).

3.- June to July.

4.-Meadows and lanes in chalky and limestone districts.

\section{Lycrena arion.-LARGE BLUE.}

1.- The rarest of the Blues inhabiting the South-east of England. A few years ago it seemed to be dying out in this country, but has lately been a little more plentiful. Unknown in Scotland and Ireland.

2.-Wild Thyme (Thymus serpyllum).

3.-June to July.

4.-Rough, broken ground on hillsides, and flowery pastures near woods. 



\section{Nemeobius lucina.-Duke of Burgundy.}

1.-A somewhat uncommon but widely distributed insect in England; it seems to be scattered over most of the Southern counties, and is not unfrequent in one or two localities in the North. Specimens are recorded as having been taken in Ireland, but they all seem to require confirmation; rare in Scotland.

2.-Primrose (Primula vulgaris) and Cowslip (P.veris).

3.- June.

4.-Woods.

\section{Syrichtus Malvæ.-Grizzled Skipper.}

1.-Common, and generally distributed over England and the South of Scotland. Unknown in Ireland.

2.-Raspberry (Rubus idaus), Bramble (R. fruticosus), and Wiid Strawberry (Fragaria vescu).

3.-May to June.

4.-Grassy wood clearings and meadows near woods.

\section{Nisoniades tages.-Dingy Skipper.}

1.-Abundant throughout England, especially in the South-east ; it occurs in the South of Scotland and sparingly in a few localities in Ireland. 

2.-Bird's-foot Trefoil (Lotus coniculatus).

3.-Double-brooded; May and August.

4.-Dry flowery chalk pits and banks, hill sides and meadows.

\section{Hesperia thaumas.-Sirall Skipper.}

1.-Abundant, and widely distributed throughout England; it occurs in the South of Ireland and possibly in Scotland.

2.-Meadow Soft-grass (Holcus lanatus) and other grasses.

3.-July.

4.-Commons and outskirts of woods.

\section{Hesperia lineola.-Essex Skipper.}

1.-A somewhat recently discovered species (1891), inhabiting the Eastern counties of England; probably more common and widely distributed than is generally supposed.

2.- Various grasses.

3.- July.

4.-Woods and outskirts of woods. 



\section{Hesperia actæon.-Lulworth Skipper.}

1.-This species is perhaps the most local of our indigenous butterflies; it has only been observed in three English counties, namely, Dorsetshire, Devonshire, and Cornwall.*

2.-Wood-reed (Calamagrostis epigeios) and Couch-grass (Triticum repens).

3.-July to August.

4.- Cliffs and caves near the coast.

* Recorded by Stainten as having occurred in Warwickshire.

\section{Hesperia sylvanus.-Large Skipper.}

1.-A common insect throughout England ; it occurs in Scotland and one or two places in Ireland.

2.-Meadow Soft-grass (Holcus lanatus), Cock's-foot Grass (Dactylis glomerata), and Couch-grass (Triticum repens).

3.-May to August.

4.-Grassy banks and wood clearings, and outskirts of woods.

Hesperia comma.-Silver-SPOTTED SKIPPER.

1.-Common in the South-eastern counties of England ; rarely seen further North than the Midlands. Unknown in Scotland and Ireland. 

2.-Bird's-foot (Ornithopus perpusillus) and Bird's-foot Trefoil (Lotus corniculatus).

3.- July to August.

4.-Chalky districts.

\section{Carterocephalus palæmon.}

\section{Chequered Skipper.}

1.--Very local; it is only found in England, where it is confined to a few of the Eastern and Midland counties. More restricted in its range than formerly.

2.-Hairy Brome-grass (Bromus asper), and other grasses.

3.-June.

4.-Woods.

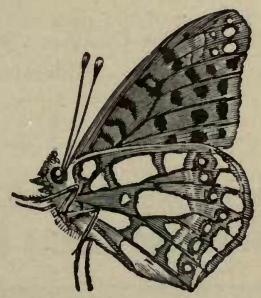

A. latona 


\section{WATKINS \& DONCASTER,}

Naturalists and Manufacturers of Entomological Apparatus and Cabinets.

N.B.-For Excellence and Superiority of Cabinets and Apparatus, references are permitted to distinguished Patrons, Colleges, \&c.

Plain Ring Nets, wire or cane including stick, 1s. 3d., 2s., 2s. 6 d.

Folding Nets, 3s. 6d. and 4s.

Umbrella Nets, 7s. (self-acting).

Pocket Boxes, 6d.; corked both sides 9 d., 1 s., and 1 s. 6 d.

Zinc Relaxing Boxes, 9d., 1s., 1s. 6d., and $2 \mathrm{~s}$.

Nested Chip Boxes, four sizes, 4 doz. 7d., 1s. 6d. gross.

Entomological Pins, mixed, 1s. 6d. per ounce.

Sugaring Lanterns, 2s. 6d. to 10s. 6 d. Sugaring Tins, with brush, 1s.6d. and $2 \mathrm{~s}$.

Sugaring Mixture (ready for use), 1s. 9 d. per tin.

Mite Destroyer (not dangerous), 1s. 6 d. per lb.

Store Boxes, with camphor cells, 2s. 6 d., and 4 s., 5 s. and 6 s.
Ditto, book patterns, 8s. 6d., 9s. 6d., and 10 s. $6 \mathrm{~d}$.

Setting Boards, flat or oval.

Setting House, 9s. 6d., and 11s. 6d. ; corked back, $14 \mathrm{~s}$.

Zinc Larva Boxes, 9d. and 1s.

Brass Chloroform Bottle, 2s. 6d.

Breeding Cages, 2s. 6d., 4s., 5s., and 7s. $6 \mathrm{~d}$.

Insect Cases, imitiation mahogany, 2s. $6 \mathrm{~d}$. to $11 \mathrm{~s}$.

Cement for replacing antennæ, $\mathbf{4 d}$.

Forceps for removing insects, 1s. $6 \mathrm{~d}$., 2s., and 2s. 6 d.

Entomological Pins, 6d., 9d., 1s. and 1s. 6d. per box.

Cabinet Cork, 7in. by $3 \frac{1}{2}$ in., 1s. and 1s. 4d. per doz. sheets.

Pupa Diggers, 1s. 9d. Insect Lens 1s. to $8 \mathrm{~s}$.

Glass-top and Glass-bottom Boxes, from 1s. 4 d. per doz.

All articles enumerated kept in stock, and can be supplied immediatcly on reccipt of order.

\section{CABINERS (Special Show Rooms).}

The following are prices of a few of the smaller sizes; for measurement and other larger sizes, \&c., apply for our new Catalogue (96 pp.). Post free.

\begin{tabular}{rccccccccccc} 
& & \multicolumn{4}{c}{ Insects. } & Eggs. & \multicolumn{4}{c}{ Minerals, Dried Plants, Fossils, \&c. } \\
4 & Drawers & $\ldots$ & $13 / 6$ & $\ldots$ & $12 /-$ & $\ldots$ & $\ldots$ & $\ldots$ & $\ldots$ & $\ldots$ & $10 / 6$ \\
6 & $\ldots$ & $\ldots$ & $17 / 6$ & $\ldots$ & $16 / 6$ & $\ldots$ & $\ldots$ & $\ldots$ & $\ldots$ & $\ldots$ & $15 /-$ \\
8 & $\ldots$ & $\ldots$ & $33 /-$ & $\ldots$ & $30 /-$ & $\ldots$ & $\ldots$ & $\ldots$ & $\ldots$ & $\ldots$ & $25 /-$ \\
10 & $\ldots$ & $\ldots$ & $45 /-$ & $\ldots$ & $56 /-$ & $\ldots$ & $\ldots$ & $\ldots$ & $\ldots$ & $\ldots$ & $45 /-$
\end{tabular}

A LARGE STOCK OF INSECTS AND BIRDS' EGGS. Birds, Mammals, \&c. Preserved and Mounted by̆ First-class Workmen. 


\section{OVA, LARVE AND PUPA OF OUR \\ BRITISH BUTTERFLIES AND MOTHS.}

\section{LARGEST STOCK IN ENGLAND.}

Intending Purchasers are cordially invited to visit my fine Breeding Grounds.

GENUINE BRITISH SPECIES ONLY REARED.

$I=$ Many very Rare Ones now on sale.

Freshly-killed Unset Insects of many species can be supplied during the Summer.

\section{SPECIAL OFFER:-}

Assorted Pupæ (good species) ... 25, 2/6;

$50,4 / 6 ; 75,6 / 6 ; 100,8 /=$;

$250,20 /=; 500,37 / 6$.

For Price List, etc., apply to 
Works by W. J. LUCAS, B.A., F.E.S.

\section{“BRITISH DRAGONFLIES."}

Being an exhaustive treatise of our native Odonata, their COLLEC'TION,

$$
\begin{aligned}
& \text { CLASSIFICATION, } \\
& \text { and PRESERVATION. }
\end{aligned}
$$

Very fully Illustrated with about 40 Coloured Plates and numerous Black and White Engravings.

Demy 8vo. In Cloth Gilt 31s. 6d.

\section{“THE B00K OF BRITISH BUTTERFLIES." \\ A Practical Manual for Collectors.}

Splendidly Illustrated with very accurate Engravings of the Caterpillars, Chrysalids, and Butterflies.

- 3s. 6a.

"THE BOOK OF BRITISH HAWK MOTHS."

WITH

Numerous Exquisite Illustrations from

Drawings by the Author.

- 3s. 6d.

\section{LONDON : \\ L. UPCOTT GILL,}

Bazaar Buildings, Drury Lane, W.C. 


\section{"THE ENTOMOLOGIST,"}

An Illustrated Journal of General Entomology.

\section{Edited by RICHARD SOUTH, F.E.S.,}

WITH THE ASSISTANCE OF

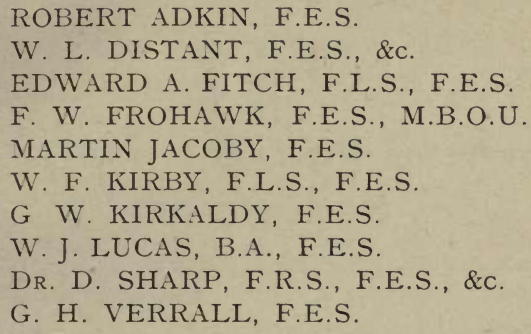

Contains original articles on every branch of the science; notes on the habits and occurrence of Lepidoptera, Coleoptera, Hymenoptera, Diptera, \&c.; proceedings of Societies, Reviews, \&c.; occasional Lithographed Plates and Wood Cuts; Monthly Lists of Duplicates and Desiderata.

\section{Price 6d.}

Subscription for One Year, including Postage and all Double Numbers, $6 \mathrm{~s}$.

\section{"THE ENTOMOLOGISTS' SYNONYMIC LIST OF BRITISH LEPIDOPTERA,"}

By Richakd South, F.E.S.

For Reference only, price $6 \mathrm{~d}$.

In Duplicate: Printed on one side only of fine cream-wove paper for Labels and on both sides for reference, Price 2/-.

LONDON :

WEST, NEWMAN \& Co., 55 Hatton Garden. SIMPKIN, MARSHALL, HAMILTON, KENT \& Co., Ltd. 


\section{W. HY. HEATHCOTE, F.L.S., NATUIRAIIST.}

Maker of Natural History and Scientific

Apparatus, \&c.

Microscopes, Cameras, and Accessorics by all the leading makers.

47 Frenchwood Street, and 119a Fishergate, PRESTON.

\section{BRITISH BUTTERFLIES AND MOTHS}

Well Set, Properly Authenticated, and in Perfect Condition.

THE FINEST SPECIMENS OBTAINABLE ARE SUPPLIED BY

W. H. HARWOOD \& SON, COLCHESTER.

Also Typical Specimens or Large Collections of all other orders of British Insects.

Living Larvæ and Pupæ of Lepidoptera, sc., \&c. 


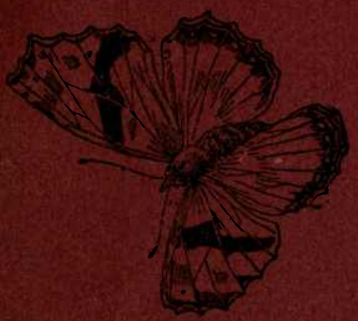


